\title{
International Registration of Cultivar Names for Unassigned Woody Genera July 2002-June 2003
}

\author{
Mark C. Tebbitt ${ }^{1}$ \\ Brooklyn Botanic Garden, 1000 Washington Avenue, Brooklyn, NY 11225-1099, U.S.A.
}

\begin{abstract}
During the period July 2002 to June 2003, six cultivar names in unassigned woody genera were registered. Individuals introducing new cultivars of ornamental plants are encouraged to register these names with a view to nomenclatural stabilization. A directory of International Registration Authorities is available at http://www.ishs.org/sci/icralist/ icralist.htm and from the American Association of Botanical Gardens and Arboreta, 100 West 10th St., Suite 614, Wilmington, DE 19081.

The present International Registration Authority for unassigned woody ornamentals can be contacted at the address above.
\end{abstract}

Phygelius 'Ivory Twist'. Registered 5 Aug. 2002. Registrant: Mr. Stuart Roycroft, Home-Plants Nursery, 52 Dorman Avenue, North Aylesham, Canterbury, Kent, CT3 3BW, UK. Phygelius 'Ivory Twist' was selected in 2001 as a self-fertilized seedling of P. rectus 'Flamingo Twist'. The new cultivar has the vegetative habit of $P$. rectus 'Moonraker' but differs in having flowers with corolla tubes that are white on their outer surfaces (RHS Colour Chart greyed-white group 156D) and yellow on the inner surfaces (RHS Colour Chart greyed-yellow group 161A). This new cultivar prefers full sun and well-drained soil and is hardy in zones 7-8 (USDA). A photograph has been deposited at the Brooklyn Botanic Garden.

Phygelius 'Sweet Dreams'. Registered 5 Aug. 2002. Registrant: Mr. Stuart Roycroft, Home-Plants Nursery, 52 Dorman Avenue, North Aylesham, Canterbury, Kent, CT3 3BW, UK. Phygelius 'Sweet Dreams' was selected in 2001 as a self-fertilized seedling of $P$. rectus 'Flamingo Twist'. This new cultivar differs from other Phygelius taxa in having flowers with corolla tubes that are ruby red on the outer surfaces (RHS Colour Chart Red group 53D) and yellow on the inner surfaces (RHS Colour Chart green-yellow group 1D). This new cultivar prefers full sun and well-drained soil and is hardy in zones 7-8 (USDA). A photograph has been deposited at the Brooklyn Botanic Garden.

Abelia 'Pleasant Surprise'. Registered 31 Oct. 2002. Registrant: Mr. Bryan D. Yeo, Pleasant View Nursery, Two Mile Oak, Newton Abbot, Devon TQ126DG, U.K. Abelia 'Pleasant Surprise' was selected in 2000 from a hybrid of Abelia $\times$ grandiflora $\times$ chinensis that was introduced to the U.K. under the incorrect name Abelia zanderi. Abelia 'Pleasant Surprise' has a more compact habit than its parents and is intermediate in certain of its leaf and flower characteristics: the leaves of Abelia 'Pleasant Surprise' are more lustrous than those of A. chinensis yet lack the bronze tinge of $A . \times$ grandiflora, the perianth of the new cultivar is intermediate in length between those of $A$. chinensis and A. $\times$ grandiflora, and the sepals are the deeper pink than those of A. chinensis but not as dark as those of $A . \times$ grandiflora. This new cultivar prefers full sun and well-drained soil and is hardy to zone 7b (USDA). This cultivar is not currently available commercially. A herbarium specimen has been deposited at the Brooklyn Botanic Garden.

Acer palmatum 'Twombly's Red Sentinel'. Registered 4 Dec. 2002. Registrant: Mr. Ken Twombly, 163 Barn Hill Road, Monroe, CT 06468. Acer 'Twombly's Red Sentinel' was selected in the late 1970s from a sport of Acer palmatum that Twombly's Nursery found in eastern Connecticut. This cultivar differs from the typical species in its compact, fastigiate growth habit and by having leaves that, in the autumn, drop over a very short period of time. It was commercially introduced in 2000 by Twombly's Nursery and first described in this nursery's reference guide. Acer 'Twombly's Red Sentinel' is hardy in USDA zones 5-7 and prefers a well-drained, humus-rich soil of $\mathrm{pH}$ 5.5-6.5. Photographic slides of this new cultivar have been deposited at the Brooklyn Botanic Garden.

Alnus maritima subspecies oklahomensis 'September Sun'. Registered 28 Mar. 2002. Registrant: Prof. William R. Graves, Dept. of Horticulture, Iowa State Univ., Ames, IA 50011-1100. Alnus maritima subspecies oklahomensis 'September Sun' was selected by William R. Graves and James A. Schrader in 1998 as a cultivated seedling grown from a wild-collected seed. A patent application is in preparation at the time of registration. Like the typical species, this cultivar forms a small tree with dark-green, glossy foliage that is attractively colored - orange, brown, and yellow - in the fall. The species is flood tolerant and has the capacity to fix nitrogen in symbiosis with the bacterial genus Frankia. The new cultivar is distinguished from the typical species by its faster growth rate, dense canopy, and uniform habit of multiple trunks that form an upright-oval shape. The name 'September Sun' refers to the yellow catkins that are produced in September. This new cultivar prefers full sun and moist positions where a portion of the root zone is saturated, such as at the edge of a pond. It is hardy in zones 3b to $7 b$ (USDA). Alnus 'September Sun' is not currently available commercially. A photograph of this cultivar has been deposited at the Brooklyn Botanic Garden.

Spiraea japonica 'Starlight'. Registered 30 June 2003. Registrant: Michael W. Farrow, 116 Saint Clements Way, Warwick, MD 21912. Spiraea japonica 'Starlight' was selected in 1997 from a sport of Spiraea japonica 'Anthony Waterer'. The new cultivar differs from Spiraea 'Anthony Waterer' by its more compact habit and more floriferous nature. Spiraea japonica 'Starlight' was first commercially introduced in 2003 at Holly Hill Farms. The new cultivar is hardy to USDA zone 4. 